Jurnal Keperawatan Hang Tuah (Hang Tuah Nursing
Journal)
e-ISSN 0000-0000

\title{
Gambaran penerapan Discharge planning pada pasien post mastektomi untuk mencegah terjadinya limfedema
}

\author{
Cindy Heben ${ }^{1}$, Rani Lisa Indra ${ }^{2}$, Susi Erianti ${ }^{3}$ \\ 1,2,3 Program Studi Keperawatan STIKes Hang Tuah Pekanbaru \\ Email: ${ }^{1}$ cindyheben77@gmail.com
}

\begin{tabular}{|c|c|}
\hline Histori artikel & Abstrak (Arial 10, dicetak tebal) \\
\hline $\begin{array}{l}\text { Received: } \\
12 \text { Desember } 2020 \\
\text { Accepted: } \\
13 \text { Februari } 2021 \\
\text { Published: } \\
17 \text { Maret } 2021\end{array}$ & $\begin{array}{l}\text { Latar Belakang : Kanker adalah suatu penyakit yang dapat } \\
\text { mematikan, diketahui dari setiap } 11 \text { menit ada satu orang } \\
\text { penduduk dunia yang meninggal karena kanker, dan merupakan } \\
\text { sebuah jenis penyakit dimana adanya sekelompok sel yang } \\
\text { tumbuh kemudian tidak terkendali dan berkembang di dalam sel } \\
\text { melebihi batas normal. Zat asing seperti bahan kimia, radiasi, virus, } \\
\text { serta zat berbahaya lainnya yang berasal dari lingkungan masuk } \\
\text { kedalam tubuh untuk merusak mekanisme kontrol dalam tubuh } \\
\text { kedalam jaringan sekitarnya dan merusak bahkan menyebar ke } \\
\text { seluruh bagian tubuh melalui cairan limfe dan darah. Desain : Jenis } \\
\text { penelitian ini adalah kuantitatif dengan Desain deskriftif } \\
\text { menggunakan pendekatan cross sectional, yaitu suatu penelitian } \\
\text { yang bertujuan untuk mendeskripsikan ( memaparkan) dari } \\
\text { fenomena yang terjadi dan menekankan waktu pengukuran / } \\
\text { observasi data hanya satu kali pada satu waktu. Hasil : Analisis } \\
\text { univariat akan ditampilkan karakteristik responden dan distribusi } \\
\text { frekuensi dari masing-masing variabel untuk gambaran } \\
\text { pencegahan limfedema terhadap penerpan discharge planning } \\
\text { oleh perawat pada pasien post mastektomi di Rumah Sakit Umum } \\
\text { Daerah Arifin Ahcmad Provinsi Riau, diantaranya } \\
\text { pelamin, lama bekerja, dan pencegahan limfedema. Rerata usia } \\
\text { perawat Rumah Sakit Umum Daerah Arifin Achmad Provinsi Riau }\end{array}$ \\
\hline
\end{tabular}


adalah 31,93 tahun, dengan standard deviasi 2,417 Tahun.

Mayoritas perawat di Rumah Sakit Umum Daerah Arifin Achmad

Provinsi Riau berjenis kelamin perempuan yaitu sebanyak 20 orang

$(74,1 \%)$. Rerata lama bekerja perawat di Rumah Sakit Umum

Daerah Arifin Achmad Provinsi Riau adalah 6,26 tahun, dengan standard deviasi 1,953 Tahun. Pencegahan limfedema ke pasien di Rumah Sakit Umum Daerah Arifin Achmad Provinsi Riau terbanyak baik yaitu 17 orang (63\%).

Kata Kunci : Discharge planning, post mastektomi, limfedema.

\begin{abstract}
Background: cancer is a potentially deadly disease, know for every 11 minutes that a resident dies of cancer, and it is disease in which agroup of cells grow out of control and develop inside a cell beyond the normal border. Foreign substances like chemicals. Radiation of the virus, as well as orther harmful substances thst come from and the environment enter the body to corrupt the mekarism of the penis in the body and destroy even throught the body via limfe fluid and blood. Design : the research is a quantitative with a deskrivtive design that defines a sectional cross sectional aporoach .results : univanate analysis will show the charaeristik of both the respondens and the frequency distribution of each varabel for limfedema prevention picture on the transfer plsnning post mastectomy in tge long labor, with $31,89 \%$ years old. With a standard deviation 2,417 years, the old ruins gathered in the general in the house with a deviatin standard 1.953 years of riau.
\end{abstract}

Key word : discharge palnning, post mastektomi, limfedema

\title{
PENDAHULUAN
}

Kanker adalah suatu penyakit yang dapat mematikan, diketahui dari setiap 11 menit ada satu orang penduduk dunia yang meninggal karena kanker, dan merupakan sebuah jenis penyakit dimana adanya sekelompok sel yang tumbuh kemudian tidak terkendali dan berkembang di dalam sel melebihi batas normal.Zat asing seperti bahan kimia, radiasi, virus, serta zat berbahaya lainnya yang berasal dari lingkungan masuk kedalam tubuh untuk merusak mekanisme kontrol dalam tubuh kedalam jaringan sekitarnya dan merusak bahkan menyebar ke seluruh bagian tubuh melalui cairan limfe dan darah (Darmono, 2011). 
Berdasarkan data GLOBOCAN (Global burden of cancer) dan IARC (International Agency for Research on Cancer) pada tahun 2012 terdapat 14,1 juta kasus baru dan 8,2 juta kematian akibat kanker di seluruh dunia.Penyakit kanker merupakan salah satu penyebab kematian utama di seluruh dunia(Kemenkes RI; Ferlay et al., 2015). Terdapat lebih dari $60 \%$ kasus baru dan $70 \%$ kematian akibat kanker setiap tahunnya di Afrika, Asia dan Amerika tengah dan selatan. Sementara di Indonesia prevalensi penyakit kanker pada semua umur tahun 2013 sebesar $1,4 \%$ atau diperkirakan sekitar 347.792 orang. Provinsi Riau memiliki prevalensi penyakit kanker sebesar 0,7\% atau diperkirakan sekitar 4.301 orang (Kemenkes, 2015).Kejadian kanker meningkat dari 12,7 juta kasus menjadi 14,1 juta kasus tahun 2012. Sedangkan jumlah kematian meningkat dari 7,6 juta orang menjadi 8,2 juta pada tahun 2012 (DepKes RI, 2014).

Berdasarkan Hasil Riset Kesehatan Dasar (Riskesdas) pada tahun 2013, prevalensi kanker mencapai 4,3 per 1000 penduduk. Kanker payudara merupakan kanker yang paling sering terjadi dengan 1,67 juta penderita (Ferlay et al., 2015).Kanker payudara adalah tumor ganas pada payudara yang berasal dari kelenjar, Saluran kelenjar dan jaringan dibagian payudara serta sering menyebabkan kematian pada wanita (Kemenkes, 2013). Diketahui bahwa kanker payudara merupakan penyakit kanker dengan persentase kasus tertinggi, yaitu sebesar 43,3\% dan persentase kematian akibat kanker payudara sebesar 12,9\%. Diperkirakan 519.000 orang wanita meninggal akibat kanker payudara dan sebanyak 69\% kematian tersebut di negara yang sedang berkembang.Data Riskesdas tahun 2013 menunjukkan prevalensi kanker payudara di Indonesia adalah 61.682 kasus, jumlah penderita kanker payudara di Provinsi Riau yaitu sekitar 894 orang (kemenkes, 2015).Data dari Dinas Kesehatan Provinsi Riau tahun 2010 didapatkan 147 kasus rawat jalan dan 172 kasus rawat inap pada pasien kanker payudara diseluruh rumah sakit Provinsi Riau.

Data rekam medis RSUD Arifin Achmad Provinsi Riau menunjukkan bahwa kejadian kasus payudara pada tahun 2014 sebanyak 586 pasien dan tahun 2015 menjadi 219 pasien. Terhitung tanggal 1 januari sampai 30 November 2016, kejadian kanker payudara mengalami peningkatan sebanyak 1062 pasien dengan menjalani mastektomi sebanyak 30 orang. Tahun 2017 hingga 2018 usia 45 sampai 64 tahun dengan jumlah tertinggi penderita kanker payudara sebanyak 1.625 wanita dengan indeks kematian yang tertinggi sebanyak 38 wanita. Mastektomi atau terapi pembedahan merupakan Penatalakasanaan bahkan modalitas utama dari pengobatan kanker payudara dengan pengangkatan seluruh jaringan payudara, operasi ini dilakukan pada kanker payudara stadium dini dan lokal lanjut (Suyatno \& Emir, 2010 ).Terdapat berbagai jenis pilihan tindakkan pembedahan seperti classic radikal mastectomy 
(CRM), modified radical mastektomi (MRM), skin sparing mastectomy (SSM), dan breast conserving treatment (BCT) (Sitiatava, 2015). Terapi pembedahan secara modified radical mastectomi(MRM) ini paling sering dilakukan baik itu kanker payudara stadium dini dan lokal berupa pengangkatan seluruh jaringan payudara beserta tumor, nipple areola kompleksPasien yang sudah menjalani mastektomi dengan pengangkatan seluruh jaringan payudara beserta nodus limfe aksilaris dapat menyebabkan limfedema.

Limfedema merupakan komplikasi dari mastektomi, jika kondisi ini dibiarkan dapat menyebabkan limfedema kronis dan parah, bahkan menimbulkan hilangnya fungsi tubuh secara permanen (Yang et al., 2016). Limfedema akan berdampak negatif pada kualitas hidup pasien, mengakibatkan gangguan gerak, menghambat aktifitas harian seperti pekerjaan rumah, perawatan diri, dan terganggunya hubungan sosial (DiSipio et al., 2013). Limfedema bisa berdampak terhadap psiklogis pasien seperti munculnya kecemasan, adanya depresi, sifat isolasi sosial dan pasien tidak mau berinteraksi dengan orang lain di sekitarnnya menimbulkan adanya masalah seksual (Chachajet al. 2010). Prevalensi limfedema sekitar 11 $\%$ dan usia tua merupakan faktor resiko untuk terjadinya edema lengan yangakan berdampak pada sistem imunitas pasien, dimana timbulnya infeksi yang terjadi berulang-ulang akibat penurunan kemampuan dari reaksi imun di dalam tubuh (Yuwono, 2010).

\section{METODE}

Jenis penelitian ini adalah kuantitatif dengan Desain deskriftif menggunakan pendekatan cross sectional, yaitu suatu penelitian yang bertujuan untuk mendeskripsikan (memaparkan) dari fenomena yang terjadi dan menekankan waktu pengukuran / observasi data hanya satu kali pada satu waktu (muri,2015). Pada penelitian kali ini akan melihat gambaran pencegahan limfedema dengan penerapan Discharge planning terhadap pasien post mastektomi.

HASIL

Analisis univariat akan ditampilkan karakteristik responden dan distribusi frekuensi dari masing-masing variabel untuk gambaran pencegahan limfedema terhadap penerpan discharge planning oleh perawat pada pasien post mastektomi di Rumah Sakit Umum Daerah Arifin Ahcmad Provinsi Riau, diantaranya umur, jenis kelamin, lama bekerja, dan pencegahan limfedema. Hasil dari analisis univariat yang didapatkan dalam penelitian ini dapat dilihat dalam tabel berikut

Tabel 1 Distribusi Usia Perawat di Rumah Sakit Umum Daerah Arifin Achmad Provinsi Riau

\begin{tabular}{lllll}
\hline Mean & Median & SD & Minimal & Maximal \\
\hline
\end{tabular}




\begin{tabular}{lllll}
\hline 31,93 & 32.00 & 2,417 & 29 & 38
\end{tabular}

Berdasarkan tabel 1 didapatkan bahwa, rerata usia perawat di Rumah Sakit Umum Daerah Arifin Achmad Provinsi Riau adalah 31,93 tahun, dengan standard deviasi 2,417 Tahun.

Tabel 2 Distribusi Frekuensi Jenis Kelamin Perawat di Rumah Sakit Umum Daerah Arifin Achmad Provinsi Riau

\begin{tabular}{lll}
\hline Jenis Kelamin & $\mathrm{f}$ & $\%$ \\
\hline Laki-Laki & 7 & 25,9 \\
\hline Perempuan & 20 & 74,1 \\
\hline Total & 27 & 100 \\
\hline
\end{tabular}

Berdasarkan tabel 2 didapatkan bahwa, mayoritas perawat di Rumah Sakit Umum Daerah Arifin Achmad Provinsi Riau berjenis kelamin perempuan yaitu sebanyak 20 orang (74,1\%).

Tabel 3 Distribusi Lama BekerjaPerawat di Rumah Sakit Umum Daerah Arifin Achmad Provinsi Riau

\begin{tabular}{lllll}
\hline Mean & Median & SD & Minimal & Maksimal \\
\hline 6,26 & 7,00 & 1,953 & 3 & 11 \\
\hline
\end{tabular}

Berdasarkan tabel 3 didapatkan bahwa, rerata lama bekerja perawat di Rumah Sakit Umum Daerah Arifin Achmad Provinsi Riau adalah 6,26 tahun, dengan standard deviasi 1,953 Tahun.

Tabel 4 Distribusi Frekuensi pencegahan limfedema ke pasien di Rumah Sakit Umum Daerah Arifin Achmad Provinsi Riau

\begin{tabular}{lcc}
\hline Pencegahan limfedema & $f$ & $\%$ \\
\hline Baik & 17 & 63 \\
\hline Kurang & 10 & 27 \\
\hline
\end{tabular}




\begin{tabular}{lll}
\hline Total & 27 & 100
\end{tabular}

Berdasarkan tabel 4 didapatkan bahwa, pencegahan limfedema ke pasien di Rumah Sakit Umum Daerah Arifin Achmad Provinsi Riau terbanyak baik yaitu 17 orang (63\%).

\section{PEMBAHASAN}

Jenis kelamin nerupakan karakterisik responden yang didasarkan atas perbedaan laki-laki dengan perempuan.Berdasarkan hasil penelitian yang dilakukan terhadap 27 resoponden diketahui bahwa sebagaian besar jenis kelamin responden adalah perempuan. Hasil penelitian ini memiliki kesamaan dengan penelitian suryadi (2016) bahwa perawat perempuan cendrung lebih banyak melaksanakan pemberian discharge planning, perawat mayoriitas berjenis kelamin perempuan karena naluri keibuan yang akan menunjang dalam pemberian asuhan keperawatan yang baik, perempuan lebih bersedia dalam melaksanakan maupun mematuhi perawatan yang sudah tersedia , perawat mayoritas berjenis kelamin wanita karena disatu sisi wanita dianggap mempunyai naluri keibuan yang tinggi yang akan dapat memberikan asuhan keperawatan yang baik, dan wanita cendrung lebih rajin, disipilin, teliti, dan sabar.

Berdasarkan hasil penelitan terhadap 27 responden bahwa mayoritas usia responden berada pada rentang usia 38 tahun. Menurut sopiah (2008) perawat sebagian besar sudah menikah, perawat yang sudah menikah menilai pekerjaan sangat penting kerena sudah memiliki sejumlah tanggung jawab, suatu pernikahan akan meningkatkan tanggung jawab yang dapat membuat suatu pekerjaan yang tetap menjadi sesuatu yang berharga.

Notoatmodjo (2010) berpendapat semakin tua umur seseorang pengalamannya akan semakin banyak dan mempengaruhi daya tangkap dan pola pikirnya, dengan lama dia bekerja maka semakin banyak yang dapat perawat tingkatkan dalam pelaksanaan discharge planning.

Berdasarkan penelitian yang dilakukan didapatkan bahwa penerapan discharge planning pada pasien post mastektomi sudah baik, hasil penelitian ini tidak sesuai dengan hasil penelitian yang dilakukan Agustin ( 2017) dimana discharge planning hanya dilakukan pada bagian yang penting saja, dan sering kali diabaikan oleh perawat, tingginya beban kerja menyebabkan perawat cendrung tidak melakukan discharge planning kepada pasien. Menurut Efendi (2009) discharge planning yang belum optimal dapat menyebabkan kegagalan dalam program 
perencanaan pemulangan perawatan pasien dirumah. Perawat bertanggung jawab memberikan rujukan yang sesuai dan memastikan bahwa semua informasi yang sesuai telah disediakan untuk orang-orang yang akan terlibat dalam perawatan pasien tersebut termasuk keluarganya. Pasien dan keluarganya harus mengetahui bagaimana cara manajemen pemberian perawatan dirumah dan apa yang diharapkan didalam memperhatikan masalah fisik yang berkelanjutan supaya tidak menyebabkan peningkatan komplikasi.

Menurut zees (2010) pelaksanaan discharge planning, sebagian besar belum dilaksanakan oleh perawat dirumah sakit, sesuai dengan standard dan prosedur pelaksanaan discharge planning dan tingginya beban kerja menyebabkan perawat cenderung tidak melakukan discharge planning kepada pasien. Namun pada penelitian kali ini hasil yang didapat terkhususnya pelaksanaan discharge planning pada pasien post mastektomi sudah baik dilihat dari Standar Operasional prosedur (SOP) pelaksanaan discharge planning di RSUD Arifin Ahcmad terkhusus ruang anyelir dan cendrawasih sudah baik perawat sudah melaksanakan tahapan discharge planning sesuai prosedur dengan baik, Hasil penelitian ini juga didukung oleh penelitian rofi'l ( 2011) menyatakan komunikasi terapeutik perawat sangat mempengaruhi dalam keberhasilan discharge planning, Standar Operasional Prosedur (SOP) pelaksanaan discharge planning terdiri dari 4 tahap : pengkajian, perencanaan, implementasi, dan evaluasi dalam tahapan ini perawat lebih sering untuk melakukan pengkajian, menginformasikan serta mendokumentasikan . hal ini sama dengan penelitian yang dilakukan Solvianun \& jannah (2017) bahwa pelaksanaan discharge planning oleh perawat sudah baik ini disebabkan oleh faktor personil dari pelaksanaan discharge planning, perawat dan tim kesehtatan lainnya mendiskusikan status klien untuk mempertimbangkan pemulangan pasien, dengan bekerja sama tujuan pemulangan pasien dapat dibuat oleh tim layanan kesehatan dan klien.

\section{KESIMPULAN}

Berdasarkan penelitian yang dilakukan oleh peneliti di RSUD Arifin Achmad Provinsi Riau mengenai gambaran discharge planning terhadap pasien post mastektomi di RSUD Arifin Achmad Provinsi Riau dapat diambil kesimpulan bahwa mayoritas responden dalam penelitian ini adalah berjenis kelamin perempuan sebanyak 20 responden, berdasarkan rentang usia mayoritas responden adalah pada rentang usia 30-40 tahun (lansia awal) Terkhusus di Ruang cendrawasih Dan Anyelir dengan lama bekerja paling lama 11 tahun. 


\section{SARAN}

Peneliti mengharapkan agar pihak rumah sakit dapat lebih berkoodinasi dengan pihak bidang keperawatan dalam memberikan intervensi dan untuk lebih dapat memonitoring dalam pelaksanaan discharge planning serta mempertahankan dan meningkatkan pelaksanaan discharge planning oleh perawat.

Peneliti mengharapkan agar dapat dijadikan referensi mahasiswa keperawatan yang akan melakukan pendidikan profesi dalam menyempurnakan pemberian asuhan keperawatan.

Penelitian ini dapat menjadi informasi dan referensi bagi peneliti selanjutnya dan bahan pertimbangan untuk melakukan penelitian yang berkaitan dengan fator-faktor dalam pelaksanaan discharge planning.

\section{REFERENSI}

Aini, M. (2015). Efektivitas Latihan Range Of Motion (ROM) Bahu Terhadap Peningkatan ROM Pada Pasien Post Mastektomi di RSUP H. Adam Malik Medan. Efektivitas Latihan Range Of Motion (ROM) Bahu terhadap Peningkatan ROM pada Pasien Post Mastektomi di RSUP H. Adam Malik Medan

Adnani, Hariza, (2011). IImu Kesehatan masyarakat. Yogyakarta:Nuha Medika.

Baker, A.M,. Brown, M.C,.\& Curran, L. (2012). Apatient's guide to recovery after mastectomy: Now what? New York : Demos Medical Publishing.

Bryant, R.A \& Nix, D.P. (2016).Acute \& cronic wounds : Current management concepts ( 5 th Ed). USA:E Isevier

Buckman, R.(2010). Apa yang seharusnya anda ketahui tentang kanker payudara. Yogyakarta:citra Aji pratama.

Chachaj, A., Małyszczak, K., Pyszel, K., Lukas, J., Tarkowski, R., Pudełko, M.,\& Szuba, A. (2010). Physical and psychological impairments of women with upper limb lymphedema following breast cancer treatment.Psycho-oncology, 19(3), 299-305.

Darmono.(2011). Toksikologi Genetik, pengaruh penyebab dan akibat terjadinya penyakit gangguan keturunan. Jakarta: UI press. 
DiSipio, T., Rye, S., Newman, B., \& Hayes, S. (2013). Incidence of unilateral arm lymphoedema after breast cancer: a systematic review and meta-analysis. The lancet oncology, 14(6), 500-515

Ferlay, J., Soerjomataram, I., Dikshit, R., Eser, S., Mathers, C., Rebelo, M. \& Bray, F. (2015). Cancer incidence and mortality worldwide: sources, methods and major patterns in GLOBOCAN 2012. International journal of cancer, 136(5).

Gossard.B. (2013).Disease prevention and treatment (5 th Ed). USA : Life Extension.

Hasyim, M., Prasetyo, J., \& Ghofar, A.(2016). Buku pedoman keperawatan dan etika sampai kamus keperawatan. Yogyakarta: Indoliterasi.

Kemenkes Kesehatan RI. (2016). Riset penyakit tidak menular 2016: Tumor payudara dan lesi prakanker serviks. Jakarta: badan penelitian dan pengembangan Kesehatan.

Kementrian Kesehatan RI. (2013). Pedoman teknis pengendalian kanker payudara dan kanker leher rahim. Jakarta: Direktorat pengendalian penyakit tidak menular.

Kementrian kesehatan RI. (2015). Info datin : Stop kanker. Jakarta: Pusat Data dan Informasi Kementrian Kesehatan RI.

Kholid, Ahmad, (2014). Promosi kesehatan: dengan pendekatan teori perilaku, media, dan aplikasinya untuk mahasiswa dan parktisi kesehatan. Jakarta: Rajawali pers.

McNeely, M. L., Campbell, K., Ospina, M., Rowe, B. H., Dabbs, K., Klassen, T. P \& Courneya, K. (2010). Exercise interventions for upper-limb dysfunction due to breast cancer treatment. The Cochrane Library.

Manuaba, T.W. (2010). Panduan penatalaksanaan kanker solid PERABOI 2010.Jakarta : Sagung Seto.

Marliany, H., Permana, Y., \& Permatasari, I. (2017).pelaksanaan discharge planning di rumah sakit.Jurnal IImiah Kesehatan Keperawatan, 13(1).

Noor, M.R Md .(2008). Kanser wanita pencegahan dan rawatan. Kuala lumpur: Unipress printer SDN BHD.

Notoatmodjo, S. (2011).Kesehatan Masyarakat IImu dan Seni.Jakarta : Rineka Cipta.

Notoatmodjo, S. (2012).Promosi Kesehatan dan Perilaku Kesehatan.Jakarta : Rineka cipta.

Nursalam. (2011). Manajemen Keperawatan Aplikasi Dalam Praktik Keperawatan Propesional.Jakarta Selatan: Salemba.

Nurjihaduddin, A., \& Darliana, D. (2016).Pengetahuan perawat pelaksana dengan pelaksanaan discharge planning di rsud meuraxa banda aceh. Jurnal IImiah Mahasiswa Fakultas Keperawatan, 1(1). 
Putra, Sitiatava Rizema. (2015). Buku Lengkap Kanker Payudara. Yogyakarta: Laksana.

Pemila U. (2006).Konsep Discharge Planning. Diakses pada tanggal 10 Agustus 2011 melalui: http://www.fik.ui.ac.id/. Nursalam. (2009). Manajemen Keperawatan: Aplikasi dalam Praktik Keperawatan Profesional. Jakarta: Salemba Medika.

Purnamasari, L. D., \& Ropyanto, C. B. (2012). Evaluasi Pelaksanaan Perencanaan Pulang. Jurnal Keperawatan Diponegoro, 1(1), 213-218.

Ranggiasanka, Aden. (2010). Waspada kanker pada pria dan wanita dilengkapi dengan pengobatan tradisional dan komplementer. Yogyakarta: Hanggar kreator.

Rondhianto. 2012. 'Pengaruh Diabetes Self Management Education dalam Discharge Planning terhadap Self Care Behavior Pasien Diabetes Mellitus Tipe 2'Jurnal Keperawatan Soedirman (The SoedirmanJournal of Nursing), vol. 7, No. 3, November 2012

Solehati, T., \& Kosasih, C.E. (2015).Konsep dan Aplikasi Relaksasi dalam Keperawatan Maternitas.Bandung : Refika Aditama.

Setiyawati, R. (2013). Analisis praktik klinik keperawatan kesehatan masyarakat perkotaan pada pasien kanker payudara pasca mastektomi di ruang rawat bedah gedung $A$ RSUPN Cipto Mangunkusumo Jakarta. Karya IImiah Akhir. Fakultas ilmu Keperawatan Universitas Indonesia. Diperoleh dari http://lib.ui.ac.id

Siwu, L., Savitri, W., \& Hutasoit, M. (2014).Pendidikan Kesehatan berpengaruh pada tingkat pengetahuan klien tentang perawatan pasca operasi kanker payudara.Media IImu Kesehatan. 3(1), 29-35. STIkes Jenderal Ahmad Yani Yogyakarta.

Suyatno \&pasaribu., E.T. (2010). Bedah onkologi diagnosis dan terapi. Jakarta: sagung seto. Syaifuddin.(2011). Fisiologi tubuh untuk manusia untuk mahasiswa keperawatan (Ed.2). Jakarta: Salemba Medika.

Sujarwerni, V.W. (2014). Metodologi penelitian keperawatan.Yogyakarta : Gava Media.

Wiharja, A. (2016). Sudut pandang baru latihan fisik sebagai terapi penderita kanker payudara.Journalof Medicine and Health, 1 (3): 288-295. Jakarta: Universitas Indonesia Yang, E. J., Ahn, S., Kim, E. K., Kang, E., Park, Y., Lim, J. Y., \& Kim, S. W. (2016). Use of a prospective surveillance model to prevent breast cancer treatment-related lymphedema: a single-center experience. Breast cancer research and treatment, 160(2), 269-276.

Yuwono, H,S. (2010). Ilmu bedah vascular: Sains dan pengalaman praktis. Bandung: PT Refika Aditama. 
Yusuf, M. (2015).Metode Penelitian Kuantitatif, Kualitatif, Penelitian gabungan.Jakarta : PT Fajar Interpratama mandiri. 